Jurnal Sains Peternakan

Vol 6, No 1, Juni 2018, pp: 25-32

ISSN 2579-4450

\title{
PENGARUH KOMBINASI EKSTRAK BUAH NANAS DAN PEPAYA PADA KONSENTRASI YANG BERBEDA TERHADAP KADAR PROTEIN DAN LEMAK DAGING ITIK PETELUR AFKIR
}

\author{
Aju Tjatur Nugroho Krisnaningsih dan Dyah Lestari Yulianti \\ Fakultas Peternakan \\ Universitas Kanjuruhan Malang \\ Email: ajutjatur@unikama.ac.id
}

\begin{abstract}
Abstrak
Penelitian ini bertujuan untuk mengetahui pengaruh kombinasi ekstrak buah nanas dan pepaya pada konsentrasi yang berbeda terhadap kualitas daging itik petelur afkir. Metode yang digunakan adalah Rancangan Acak Lengkap (RAL) dengan konsentrasi kombinasi ekstrak nanas $(\mathrm{N})$ dan papaya $(\mathrm{P})$ sebagai perlakuan. Adapun perlakuan penelitiannya yaitu $\mathrm{P} 0(0 \% \mathrm{~N}, 0 \% \mathrm{P})$; $(\mathrm{P} 1$ $25 \% \mathrm{~N}, 75 \% \mathrm{P}) ; \mathrm{P} 2(50 \% \mathrm{~N}, 50 \% \mathrm{P})$, and $\mathrm{P} 3(75 \% \mathrm{~N}, 25 \% \mathrm{P})$. Setiap perlakuan diulang 3 kali. Variabel dalam penelitian adalah kadar protein dan kadar lemak daging itik pedaging. Hasil penelitian menunjukkan perbedaan yang signifikan untuk konsentrasi kombinasi ekstrak buah nanas dan pepaya terhadap kadar protein $(\mathrm{P}<0.01)$ dengan rataan $\mathrm{P} 0(21,98 \%), \mathrm{P} 1(17,40 \%), \mathrm{P} 2$ $(17,37 \%), \mathrm{P} 3(17,62 \%)$ dan kadar lemak $(\mathrm{P}<0.01)$ dengan rataan $\mathrm{P} 0(2,15 \%), \mathrm{P} 1(3,75 \%), \mathrm{P} 2$ $(3,41 \%)$, P3 $(3,54 \%)$. Berdasarkan hasil dapat disimpulkan bahwa percobaan terbaik adalah pada $75 \% \mathrm{~N} 25 \% \mathrm{P}$.
\end{abstract}

Kata kunci: daging itik, ekstrak, buah nanas, buah pepaya, protein, lemak

\section{The Effect Of A Combination Of Pineapple And Papaya Fruit Extracts At Different Concentrations On The Quality Of The Meat Of Post-Production Laying Ducks}

\begin{abstract}
The purpose of this study was to determine the effect of a combination of pineapple and papaya fruit extracts at different concentrations on the quality of the meat of post-production laying ducks. The method used was a Completely Randomized Design (CRD) with a combination of pineapple extract $(\mathrm{N})$ and papaya $(\mathrm{P})$ as a treatment. The research treatment is $\mathrm{P} 0(0 \% \mathrm{~N}, 0 \% \mathrm{P})$; $(\mathrm{P} 125 \% \mathrm{~N}, 75 \% \mathrm{P}) ; \mathrm{P} 2(50 \% \mathrm{~N}, 50 \% \mathrm{P})$, and $\mathrm{P} 3(75 \% \mathrm{~N}, 25 \% \mathrm{P})$. Each treatment was repeated 3 times. The variables in the study were protein content and fat content of broiler duck meat. The results showed a significant difference for the concentration of the combination of pineapple and papaya fruit extracts on protein content $(\mathrm{P}<0.01)$ with an average $\mathrm{P} 0(21.98 \%), \mathrm{P} 1(17.40 \%), \mathrm{P} 2$ $(17.37 \%), \mathrm{P} 3(17.62 \%)$ and fat content $(\mathrm{P}<0.01)$ with an average P0 $(2.15 \%), \mathrm{P} 1(3.75 \%), \mathrm{P} 2$ $(3.41 \%), \mathrm{P} 3(3.54 \%)$. Based on the results it can be concluded that the best experiment is at $75 \% \mathrm{~N}$ $25 \% \mathrm{P}$.
\end{abstract}

Key words : ducks meat, extract, pineapple, papaya, crude protein, extract eter

\section{PENDAHULUAN}

Di negara berkembang seperti Indonesia dari tahun-ketahun kebutuhan akan bahan makanan yang bergizi semakin meningkat sejalan dengan bertambahnya jumlah penduduk. Kesadaran akan pentingnya gizi demi usaha kesehatan, pertumbuhan, kecerdasan dan kekuatan fisik serta didukung oleh semakin baiknya pendapatan masyarakat menyebabkan kebutuhan akan makanan yang berkualitas meningkat, salah satunya adalah daging, karena daging merupakan sumber protein hewani. Seperti yang 


\section{Jurnal Sains Peternakan}

Vol 6, No 1, Juni 2018, pp: 25-32

ISSN 2579-4450

dilaporkan olah Ditjetnak (2013) bahwa peran ternak itik sebagai penghasil daging masih rendah, pada tahun 2012 produksi daging itik sebesar 30.053 ton dengan kebutuhan konsumsi daging Nasional mencapai 1.753,54 ribu ton (Anonimus, 2013).

Daging itik afkir dapat dimanfaatkan sebagai sumber protein dan lemak hewani, juga memiliki kandungan kalori relatif lebih rendah serta kandungan vitamin B lebih tinggi dibandingkan daging unggas lainnya. Didukung oleh hasil analisa proksimat pada penelitian Shawkat, dkk (2007) menunjukkan kandungan komposisi nutrisi kadar air, protein dan lemak pada bagian dada itik dan ayam tidak banyak berbeda. Itik afkir adalah itik petelur yang berusia 20-24 bulan sehingga tidak layak lagi dipelihara sebagai itik petelur. Dalam rangka meningkatkan konsumsi daging itik afkir, daging itik dapat di olah dengan cara dimasak, digoreng, dipanggang dan dapat diolah menjadi produk olahan lainnya yang menarik dan lebih bervariasi untuk dikonsumsi masyarakat.

Pada kenyataannya kondisi di lapang menunjukkan bahwa konsumen lebih memilih itik pedaging dari pada itik petelur afkir. Hal ini disebabkan karena daging itik petelur yang sudah afkir memiliki tekstur daging yang keras atau liat jika digigit serta membutuhkan waktu yang lama dalam proses pengempukan maupun pemasakan. Kelemahan daging itik afkir terutama dalam hal keempukan, hal ini disebabkan karena semakin tua umur ternak, maka jumlah jaringan ikat lebih banyak, sehingga meningkatkan keliatan daging (Fletcher, 2007).

Berdasarkan pernyataan Istrati, Vizireanu dan Dinica (2011) metode peningkatan kualitas daging itik, yakni melalui pemanfaatan enzim golongan protease. Enzim golongan protease ini yang berfungsi untuk mendegradasi kolagen daging, sehingga diperoleh daging itik yang liat menjadi empuk, juicy dan memiliki cita rasa yang khas (Qihe, 2006). Selain itu menurut Rawendra (1989) daging yang empuk dapat diperoleh dengan berbagai cara seperti dibungkus daun pepaya, diberi enzim papain, direndam dalam ekstrak buah nanas atau diberi enzim bromelin.

Enzim bromelin dan papain merupakan golongan enzim protease yang banyak terdapat pada buah nanas dan pepaya (Bille and Taapopi, 2008). Didukung oleh hasil penelitian Utami, Pudjomartatmo dan Nuhriawangsa (2011) bahwa terdapat adanya peningkatan keempukan, $\mathrm{pH}$, daya ikat air dan penurunan susut masak daging itik dengan penambahan $15 \%$ ekstrak buah nanas dan waktu pemasakan 60 menit. Sedangkan hasil penelitian Tami, Radiati dan Widyastuti menunjukkan bahwa penambahan ekstrak nanas $(0 \%, 25 \%$ dan 50\%) dan lama perendaman (0 menit, 15 menit dan 30 menit) pada daging ayam kampung tidak meningkatkan kualitas kimia (kadar air, kadar lemak dan kadar protein), sehingga diperlukan penambahan ekstrak nanas dengan konsentrasi yang lebih 


\section{Jurnal Sains Peternakan}

Vol 6, No 1, Juni 2018, pp: 25-32

ISSN 2579-4450

tinggi untuk mengetahui efektivitas maksimum pengaruh ekstrak nanas pada perubahan kualitas daging ayam kampung.

Enzim papain merupakan enzim protease yang dapat diekstrak dari bagian pohon pepaya terutama pada daun dan buah pepaya. Penggunaan enzim papain lebih mudah mengingat pohon pepaya tersebar hampir di semua daerah dan mudah didapat. Hasil penelitian Setyawardani dan Haryoko (2005) menunjukkan bahwa perendaman menggunakan enzim papain dalam bentuk getah pepaya denga konsentrasi $0,4 \%$ dan lama perendaman 30 menit menghasilkan karakteristik optimum dari daging kambing betina yang berumur tua pada tingkat keempukan $7,18 \mathrm{~mm} / 50 \mathrm{~g} / 10 \mathrm{det}$, nilai susut masak sebesar 47,49\%, daya mengikat air sebesar 6,36\% dan daging segar dalam kondisi asam dengan nilai rata-rata $\mathrm{pH} 5,73$. Buah nanas dan pepaya merupakan buah yang selalu tersedia dan dipanen sepanjang tahun serta tersebar di Indonesia, sehingga enzim bromelin dan papain mudah diperoleh dan dapat dimanfaatkan sepanjang waktu.

Berdasarkan uraian di atas maka perlu dilakukan penelitian terkait dengan pengaruh kombinasi ekstrak buah nanas dan pepaya pada konsentrasi yang berbeda terhadap kadar protein dan lemak daging itik petelur afkir, sebagai salah satu metode untuk mengolah daging itik afkir yang liat sehingga dapat meningkatkan kualitas daging itik sebagai salah satu sumber protein hewani dan dapat diaplikasikan oleh masyarakat dalam kehidupan sehari-hari.

\section{MATERI DAN METODE}

Materi penelitian yang digunakan adalah daging bagian dada dan paha dari itik petelur Mojosari afkir yang berumur 27 bulan, kombinasi ekstrak nanas dan ekstrak pepaya. Metode yang digunakan dalam penelitian ini adalah percobaan laboratorium dengan menggunakan Rancangan Acak Lengkap (RAL) yang terdiri dari 4 perlakuan dan masing-masing perlakuan terdiri dari 3 ulangan. Adapun perlakuan penelitiannya yaitu P0 $(0 \% \mathrm{~N}, 0 \% \mathrm{P}) ;(\mathrm{P} 125 \% \mathrm{~N}, 75 \% \mathrm{P}) ; \mathrm{P} 2(50 \% \mathrm{~N}, 50 \% \mathrm{P})$, and $\mathrm{P} 3(75 \% \mathrm{~N}, 25 \% \mathrm{P})$.

Data yang diperoleh dianalisis dengan menggunakan anova dan apabila antar perlakuan terdapat perbedaan maka dilanjutkan dengan uji Beda Nyata Terkecil (BNT).

\section{HASIL DAN PEMBAHASAN}

\section{Pengaruh Kombinasi Ekstrak Nanas dan Pepaya Terhadap Kadar Protein Daging Itik Petelur Afkir}

Berdasarkan hasil analisa statistik menunjukan bahwa kombinasi konsentrasi ekstrak nanas dan pepaya memberikan pengaruh yang sangat nyata $(\mathrm{P}<0,01)$ terhadap 


\section{Jurnal Sains Peternakan}

Vol 6, No 1, Juni 2018, pp: 25-32

ISSN 2579-4450

kadar protein pada daging itik petelur afkir. Rata-rata nilai kadar protein (\%) daging itik petelur afkir dari masing-masing perlakuan disajikan pada Tabel 1.

Tabel 1. Rerata kadar protein daging itik petelur afkir

\begin{tabular}{lr}
\hline Perlakuan & Rataan $(\%)$ \\
\hline P0 & $22,01^{\mathrm{b}}$ \\
P1 & $17,40^{\mathrm{a}}$ \\
P2 & $17,37^{\mathrm{a}}$ \\
P3 & $17,62^{\mathrm{a}}$ \\
\hline
\end{tabular}

Keterangan : Notasi yang berbeda menunjukan adanya perbedaan yang sangat nyata pada masing-masing perlakuan $(\mathrm{P}<0,01)$.

\section{Rata-rata Protein Kasar}

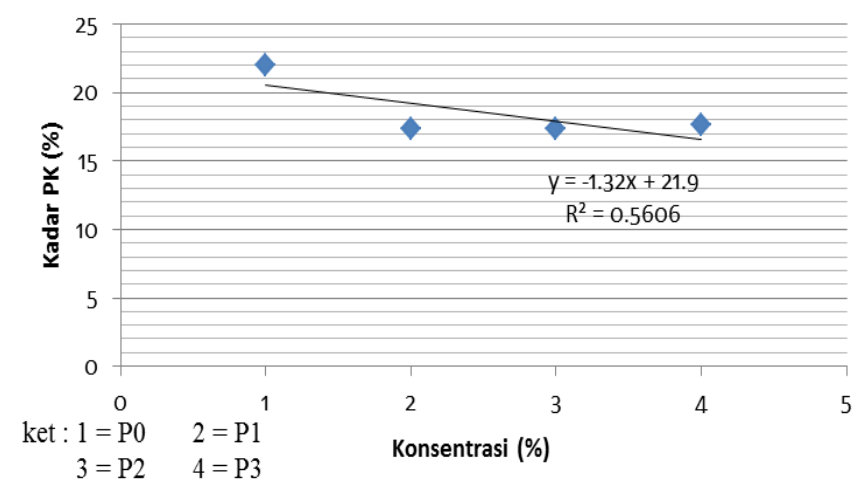

Berdasarkan hasil perhitungan kadar protein yang telah dilakukan dapat terlihat bahwa kadar protein tertinggi terdapat pada P0 yaitu tanpa penambahan ekstrak nanas dan pepaya $(0 \% \mathrm{~N} 0 \% \mathrm{P})$ dimana protein belum mengalami hidrolisis menjadi asam amino, sedangkan pada $\mathrm{P} 1, \mathrm{P} 2$, dan $\mathrm{P} 3$ dengan penambahan konsentrasi $25 \% \mathrm{~N} 75 \% \mathrm{P}, 50 \% \mathrm{~N}$ $50 \% \mathrm{P}$ dan $75 \% \mathrm{~N} 25 \% \mathrm{P}$ protein mengalami hidrolisis sehingga kadar protein menurun, terlihat dimana pada $\mathrm{P} 2$ dengan penambahan konsentrasi $50 \% \mathrm{~N} 50 \% \mathrm{P}$ memiliki rata-rata terendah yaitu 17,37\% dibandingkan dengan P1 dan P3. Dalam hal ini enzim protease mendegradasi protein menjadi asam amino atau bentuk yang lebih sederhana sehingga kadar protein menurun, sesuai dengan pendapat Ketnawa dan Rawdkuen (2011) bahwa kadar protein turun karena terjadi degradasi struktur protein atau proteolisis kolagen menjadi hidroksiprolin sehingga menghasilkan fragmen protein dengan rantai peptida lebih pendek. Semakin banyak proteolisis maka protein terlarutnya semakin banyak sehingga kadar protein turun. Enzim sendiri merupakan protein tapi tidak ikut menjadi hasil reaksi, hanya mempercepat atau memperlambat reaksi saja, oleh sebab itu jika lingkungan (suhu dan $\mathrm{pH}$ ) yang digunakan optimal maka enzim akan bekerja maksimal.

Pada suatu konsentrasi substrat tertentu, kecepatan reaksi bertambah dengan bertambahnya konsentrasi enzim. Hal ini sesuai dengan pendapat Ferdiansyah (2005), 


\section{Jurnal Sains Peternakan}

Vol 6, No 1, Juni 2018, pp: 25-32

ISSN 2579-4450

bahwa kecepatan katalisis akan semakin meningkat dengan meningkatnya konsentrasi enzim, sesuai dengan pendapat (Lewrie 2003) bahwa cara kerja enzim ini yaitu dengan cara memecahkan molekul protein melalui kegiatan hidrolisis protein. Enzim mula-mula akan merusak mukopolisakrida dari matriks substansi dasar, kemudian secara cepat menurun keserat-serat tenunan pengikat. Menurut Zulfahmi, dkk (2013) peningkatan level pemberian enzim protease pada daging itik tegal afkir dapat meningkatkan hidrolisa protein-protein daging.

Bromelin yang terkandung dalam ekstrak buah nanas memiliki kemampuan untuk memecah molekul-molekul protein menjadi bentuk lebih sederhana (asam amino) (Sunarsih, 2008), dengan memotong ikatan pada struktur protein jaringan ikat. Menurut Radiati (2010), bahwa enzim bromelin merupakan enzim endo protease, aktivitas enzim bromelin optimum pada $\mathrm{pH}$ 6,5 dimana enzim ini mempunyai konformasi yang mantap dan juga mempunyai aktivitas yang maksimum dan suhu optimum untuk enzim bromelin adalah $50^{\circ} \mathrm{C}$, di atas atau di bawah suhu tersebut keaktifan enzim menjadi lebih rendah.

Fungsi enzim bromelin dan papain hampir sama sebagai enzim protease yang mengubah struktur kuartener protein menjadi lebih sederhana. Proses pengempukan daging dengan menggunakan enzim papain akan terjadi perubahan-perubahan yaitu berupa hancurnya sarkolema, diikuti larutnya nucleus dan terjadi penurunan ikatan antar serabut otot, sehingga serabut otot terputus-putus dan sifatnya mudah dipisah-pisahkan, akibatnya daging menjadi lunak (Istrati, dkk, 2011). Kisaran pH optimum papain berkisar antara 5-7,5 dan stabil pada suhu 60-70 ${ }^{\circ} \mathrm{C}$. Sedangkan Gerelt, dkk (2000) menyatakan bahwa enzim papain dapat merombak protein menjadi molekul yang lebih sederhana seperti asam amino serta dapat mempengaruhi keempukan daging dengan cara mendegradasi protein sarkomer.

Terjadinya denaturasi protein dapat menyebabkan keempukan pada daging dikarenakan ikatan serat terpecah sehingga menjadi fragmen yang lebih pendek dan serabut otot mudah terpisah. Hal ini sesuai dengan pendapat Istika (2009) yang menyatakan bahwa protein (kolagen dan miofibril) terhidrolisis menyebabkan hilangnya ikatan antar serat dan pemecahan serat menjadi fragmen yang lebih pendek, menjadikan serat otot lebih mudah terpisah sehingga daging lebih empuk. 


\section{Jurnal Sains Peternakan}

Vol 6, No 1, Juni 2018, pp: 25-32

ISSN $2579-4450$

\section{Pengaruh Kombinasi Ekstrak Nanas dan Pepaya Terhadap Kadar Lemak Daging} Itik Petelur Afkir

Berdasarkan hasil analisa statistik menunjukan bahwa penambahan konsentrasi ekstrak buah nanas dan pepaya pada daging itik petelur afkir memberikan pengaruh yang sangat nyata $(\mathrm{P}<0,01)$ terhadap kadar protein kadar lemak daging itik petelur afkir, karena $\mathrm{F}$ hitung lebih besar dari $\mathrm{F}$ tabel, Rata-rata nilai kadar lemak (\%) daging itik petelur afkir dari masing-masing perlakuan disajikan pada Tabel 2.

Tabel 2. Rerata kadar lemak daging itik petelur afkir

\begin{tabular}{lr}
\hline Perlakuan & Rataan $(\%)$ \\
\hline P0 & $2,15^{\mathrm{a}}$ \\
P1 & $3,75^{\mathrm{d}}$ \\
P2 & $3,41^{\mathrm{b}}$ \\
P3 & $3,54^{\mathrm{c}}$ \\
\hline
\end{tabular}

Keterangan : Notasi yang berbeda menunjukan adanya perbedaan yang sangat nyata pada masing-masing perlakuan $(\mathrm{P}<0,01)$

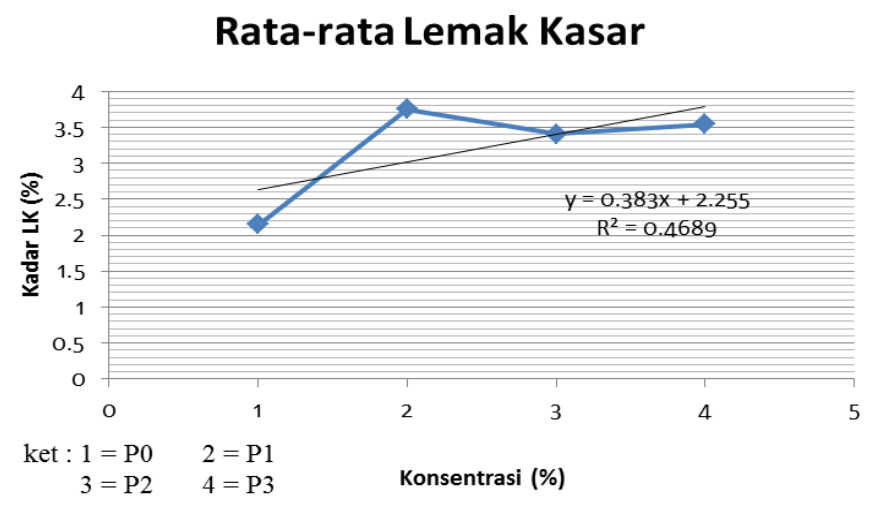

Berdasarkan hasil perhitungan kadar lemak daging itik petelur afkir yang telah dilakukan dapat terlihat bahwa penambahan ekstrak nanas dan pepaya dengan kadar lemak tertinggi yaitu pada P1 dengan konsentrasi 25\% N 75\% , sedangkan untuk kadar lemak terendah yaitu pada P0 dengan konsentrasi 0\%N 0\%P. Kombinasi ekstrak nanas dan pepaya dapat meningkatkan kadar lemak daging itik petelur afkir, variasi komposisi kimia antara kadar lemak dan protein pada daging selalu merefleksikan satu dengan lain, jika kadar protein rendah maka kadar lemak tinggi begitu sebaliknya.

Hasil penelitian Tami, Radiati dan Widyastuti (2013) menunjukkan adanya peningkatan nilai rataan kadar lemak daging ayam kampung pada konsentrasi dan lama perendaman dengan penambahan ekstrak nanas, meskipun secara statistik tidak memberikan perbedaan. Peningkatan kadar lemak dapat disebabkan karena emulsi lemak dan adanya komposisi asam lemak baru dan asam lemak bebas dari hasil kerja ke dua enzim tersebut. Diduga lemak pada ekstrak buah nanas dan pepaya ikut larut dan terhitung saat analisa laboratorium, sehingga mengakibatkan kadar lemak meningkat. 


\section{Jurnal Sains Peternakan}

Vol 6, No 1, Juni 2018, pp: 25-32

ISSN 2579-4450

Semakin tinggi lemak marbling akan membuat daging semakin empuk (Dilaga dan Soeparno, 2007).

\section{KESIMPULAN}

Berdasarkan hasil penelitian dapat disimpulkan bahwa penggunaan kombinasi ekstrak nanas dan pepaya pada konsentrasi yang berbeda dapat mempengaruhi kadar protein dan kadar lemak. Rerata kadar protein tertinggi terdapat pada P0 yaitu tanpa perlakuan, sedangkan rerata terendah yaitu pada perlakuan P2 dengan konsentrasi $50 \% \mathrm{~N}$ 50\%P. Untuk rerata kadar lemak tertinggi yaitu pada perlakuan P1 dengan konsentrasi $25 \% \mathrm{~N} 75 \% \mathrm{P}$, sedangkan rerata terendah terdapat pada $\mathrm{P} 2$ yaitu dengan konsentrasi $50 \% \mathrm{~N}$ 50\%P. Dengan demikian hasil terbaik dari ketiga perlakuan ini terdapat pada P3 karena memiliki nilai rata-rata kadar protein yang masih tinggi dan meiliki rata-rata kadar lemak yang tidak terlalu tinggi.

\section{UCAPAN TERIMA KASIH}

Ucapan terima kasih disampaikan kepada semua pihak terutama Laboratorium Terpadu Fakultas Peternakan Universitas Kanjuruhan Malang yang telah banyak membantu sejak persiapan hingga terselenggaranya penelitian ini dengan baik.

\section{DAFTAR PUSTAKA}

Anonimus. 2013. Data Lima Tahun Subsektor Peternakan http://www.deptan.go.id/infoe ksekutif/nak/pdfeisNAK2013/Pop ItikProp2013.pdf. Diakses oleh Direktorat Jenderal Peternakan, tanggal 3 November 2014.

Bille, P.G. and M.S., Taapopi. 2008. Effects of two commercial meat tenderizers on different cuts of goat's meat in Namibia. African Journal of Food Agriculture Nutrition and Development, Vol. 8, No. 4, Dec, 2008, pp. 417-426.

Dilaga, I.W.S. dan Soeparno. 2007. Pengaruh pemberian berbagai level Clenbuterol terhadap kualitas daging babi jantan grower. Buletin Peternakan Vol. 31(4):200208.

Ferdiansyah, V. 2005. Pemanfaatan Kitosan Dari Cangkang Udang Sebagai Matriks Penyangga pada Imobilisasi Enzim Protease. Skripsi. Jurusan Teknologi Hasil Pertanian. Fakultas Perikanan dan Ilmu Kelautan. Institut Pertanian Bogor. Bogor.

Fletcher, D.L . 2007. Poultry meat quality. World's Poultry Science Journal. Volume 58. Issue 02, pp 131-145

Gerelt, B, Y. Ikeuchi and A. Suzuki. 2000. Meat Tenderazion by Proteolytic Enzymes After Osmotic Dihydration. http://www.google.co.id Diakses 02 November 2000. 


\section{Jurnal Sains Peternakan}

Vol 6, No 1, Juni 2018, pp: 25-32

ISSN 2579-4450

Istika, dewi. 2009. Pemanfaatan Enzim Bromelain Pada Limbah Kulit Nanas dalam Pengempukan Daging. Jurusan Biologi Fakultas Matematika dan Ilmu Pengetahuan Alam Universitas Sebelas Maret. Surakarta.

Istrati, D.,C. Vizireanu and R. Dinică. 2011. Influence of vacuum packaging on quality of beef muscle after different tenderization methods . Journal of Agroalimentary Processes and Technologies 2011, 17(3), 275-280

Ketnawa, S and S. Rawdkuen. 2011, Application of Bromelain Extract for Muscle Foods Tenderization. Food and Nutrition Sciences, Vol. 2 No. 5, 2011, pp. 393-401.

Lawrie, R. A. 2003. Ilmu Daging. Diterjemahkan oleh Parakasi, A Edisi V. Universitas Indonesia Press. Jakarta.

Qihe. 2006. Effects of elastase from a Bacillus strain on the tenderization of beef meat. Journal of Agricultural and Food Chemistry, Food Chemistry 98 (2006) 624- 629

Rawendra, R. 1989. Ilmu Daging. Balai Pendidikan dan Pelatihan Pertanian. APP Malang.

Setyawardani, T dan I. Haryoko. 2005. Kajian Metode Pengempukan Daging Kambing Tua. Journal Animal Production, Vol.7,No.2 :106-110.

Sunarsih, L. 2008. Uji Efektivitas Ekstrak Buah Nanas (Ananas comosus L. Merr) Muda Varietas Queen Terhadap Mortalitas Cacing Parasit (Ascaridia Galli) Secara In Vitro. Skripsi. Fakultas Keguruan dan Ilmu Pendidikan. Universitas Muhamadiyah Malang. Malang.

Tami, Radiati dan Widyastuti. 2013. Pengaruh Konsentrasi Ekstrak Nanas Dan Lama Perendaman Terhadap Kadar Air, Kadar Lemak Dan Kadar Protein Daging Ayam Kampung (Gallus domesticus). Universitas Brawijaya Malang.

Utami, D. P., Pudjomartatmo dan A. M. P. Nuhriawangsa. 2011. Manfaat Bromelin dari Ekstrak Buah Nenas (Ananas comocus L. Merr) dan Waktu Pemasakan untuk Meningkatkan Kualitas Daging Itik Afkir. Sains Peternakan.

Zulfahmi M, Pramono Y.B., Hintono A. 2013. Pengaruh marinasi ekstrak kulit nenas (ananas comocus 1 . Merr) pada daging itik tegal betina afkir terhadap kualitas Keempukan dan organoleptik. Jurnal Pangan dan Gizi Vol. 4 No. 08 Tahun 2013. 